\title{
Article \\ Bioguided Isolation of Antibiofilm and Antibacterial Pregnane Glycosides from Caralluma quadrangula: Disarming Multidrug-Resistant Pathogens
}

\author{
Riham A. El-Shiekh ${ }^{1,+}+\mathbb{C}$, Mariam Hassan ${ }^{2, *,+}$ (), Rasha A. Hashem ${ }^{2}$ and Essam Abdel-Sattar $1, * \mathbb{C}$ \\ 1 Department of Pharmacognosy, Faculty of Pharmacy, Cairo University, El-Kasr El-Aini Street, \\ Cairo 11562, Egypt; riham.adel@pharma.cu.edu.eg \\ 2 Department of Microbiology and Immunology, Faculty of Pharmacy, Cairo University, El-Kasr El-Aini Street, \\ Cairo 11562, Egypt; rasha.hashem@pharma.cu.edu.eg \\ * Correspondence: mariam.hassan@pharma.cu.edu.eg (M.H.); essam.abdelsattar@pharma.cu.edu.eg (E.A.-S.); \\ Tel.: +20-(122)-337-6326 (M.H.); +20-(106)-584-7211 (E.A.-S.) \\ + Both authors are considered first authors and have equal contributions.
}

Citation: El-Shiekh, R.A.; Hassan, M.; Hashem, R.A.; Abdel-Sattar, E. Bioguided Isolation of Antibiofilm and Antibacterial Pregnane Glycosides from Caralluma quadrangula: Disarming Multidrug-Resistant Pathogens. Antibiotics 2021, 10, 811. https:// doi.org/10.3390/antibiotics10070811

Academic Editor: Emanuela Roscetto

Received: 17 May 2021

Accepted: 29 June 2021

Published: 3 July 2021

Publisher's Note: MDPI stays neutral with regard to jurisdictional claims in published maps and institutional affiliations.

Copyright: () 2021 by the authors. Licensee MDPI, Basel, Switzerland. This article is an open access article distributed under the terms and conditions of the Creative Commons Attribution (CC BY) license (https:// creativecommons.org/licenses/by/ $4.0 /)$.

\begin{abstract}
Methicillin-resistant Staphylococcus aureus (MRSA) and multidrug-resistant Acinetobacter baumannii (MDRAB) present a serious challenge because of their capability to cause biofilm resistance to commonly used antibiotics producing chronic infections and hindering the process of wound healing. In the current study, we investigated the antibacterial activity of Caralluma quadrangula extracts ( $\mathrm{MeOH}$, and its fractions $\mathrm{CH}_{2} \mathrm{Cl}_{2}$ and $n$-butanol) against multidrug-resistant MRSA USA300 and $A$. baumannii $\mathrm{AB} 5057$. In vitro, the $\mathrm{MeOH}$ extract and both fractions of $C$. quadrangula significantly inhibited biofilm formation and disrupted previously established biofilm by MRSA and MDRAB at all the tested concentrations $(0.625,0.313$, and $0.156 \mathrm{mg} / \mathrm{mL})$. In vivo, C. quadrangula extracts successfully decreased bacterial loads in MRSA-infected skin lesions in mice. Four pregnane glycosides and one flavone glycoside were isolated from the bioactive $n$-butanol fraction. The isolated compounds (Rus A-E) were tested for their biofilm inhibition and biofilm detachment activities. The results revealed that Rus $C$ was the most active compound $\left(\mathrm{IC}_{50}=0.139 \mathrm{mmole}\right)$, while Rus $\mathrm{E}$ was the least active $\left(\mathrm{IC}_{50}=0.818\right.$ mmole) . These results support the potential use of $C$. quadrangula extracts or their isolated compounds for hindering the biofilm attachment and the virulence of MRSA and MDRAB and their application as a topical antimicrobial preparation for MRSA skin infections.
\end{abstract}

Keywords: antivirulence; Acinetobacter baumannii; Caralluma quadrangula; in vivo; methicillin-resistant Staphylococcus aureus (MRSA); pregnane glycosides; skin infection

\section{Introduction}

Methicillin-resistant Staphylococcus aureus (MRSA) and multidrug-resistant Acinetobacter baumannii (MDRAB) are opportunistic pathogens. They are well fitted to hospital environments, and the perseverance of their chronic infections is mainly due to their capability to form biofilm and resist the host immune system [1,2]. The emergence of microbial resistance to numerous conventional antibiotics has become a serious global concern. These microbes cause serious bloodstream infections, urinary tract infections, wound infections, pneumonia, and secondary meningitis with high morbidity and mortality rates [3-5]. MRSA and MDRAB are the most commonly encountered pathogens in hospitals [6,7]. Drug resistance and biofilm formation appear to play a critical condition in the pathogenicity of MRSA and MDRAB $[1,2,8]$. The majority of $A$. baumannii were found to be multidrug-resistant strains. Carbapenem-resistant $A$. baumannii was reported among the predominant isolates that emerged in healthcare systems [9]. Recently, colistin-resistant strains have been isolated from wounds and hospital-resident patients, which is considered as the last line of defense against multidrug-resistant strains [10,11]. Hence, screening 
new naturally occurring candidates for fighting these microbes is seriously needed, as these natural resources represent rich reservoirs for new antimicrobials and bioactive metabolites [12-14].

Several members of the genus Caralluma are succulent perennial edible plants with several traditional uses such as antiinflammatory, antidiabetic, antirheumatic, antiulcer, and wound healing $[15,16]$. Several Caralluma species or their phytoconstituents showed a wide spectrum of antimicrobial activity against fungi, Gram-positive and Gram-negative [17-21]. The major bioactive molecules identified in the members of the genus Caralluma are pregnane glycosides, flavone glycosides, terpenoids, and sterols showing a lot of therapeutic significance. Caralluma quadrangula (Forssk.) is a leafless succulent herb traditionally used for the treatment of ulcers, diabetes, and rheumatic arthritis $[15,16]$. Extract of $C$. quadrangula was applied in Saudi folk medicine in the treatment of freckles, melasma, diabetes, and vitiligo and in cases of hunger and thirst [22]. Abdel-Sattar and coworkers [23] reported a promising hypoglycemic effect for the methanolic extract of C. quadrangula $(200 \mathrm{mg} / \mathrm{kg})$ and its related fractions (dichloromethane and $n$-butanol fractions at a dose of $100 \mathrm{mg} / \mathrm{kg}$ ), as well as russelioside $B$, the major isolated pregnane glycoside. In addition, a major isolated pregnane glycoside, russelioside $B$, showed several biological activities viz. antidiabetic [24], antiobesity [25], antiarthritic agent [26], and antiulcer [27]. Several Caralluma species showed a wide spectrum of antibacterial and/or antifungal activity [20,21].

Therefore, we investigated the antibiofilm and antibacterial activity of C. quadrangula extracts opposed to MRSA USA300 and MDRAB AB5057 in vitro. In addition, we accessed their efficacy in MRSA skin infection lesions in vivo.

\section{Results}

2.1. Minimum Bactericidal Concentration (MBC) and Antibiofilm Assays for C. quadrangula Extracts

C. quadrangula extracts (Cq1: methanolic extract, Cq2: methylene chloride, and Cq3: $n$-butanol fractions) were tested for in vitro antibacterial activity against MDRAB AB5057 and MRSA USA300. C. quadrangula extracts (Cq1, Cq2, and Cq3) showed antibacterial activity opposed to MDRAB AB5057 and MRSA USA300 with minimum bactericidal concentration (MBC) values of $12.5 \mathrm{mg} / \mathrm{mL}$ and $25 \mathrm{mg} / \mathrm{mL}$, respectively. The three tested extracts inhibited MDRAB AB5057 and MRSA USA300 biofilm formation significantly at the tested concentrations $(0.625,0.313$, and $0.156 \mathrm{mg} / \mathrm{mL}$ ) (two-way ANOVA and Tukey's test, $p<0.05$ ) (Figure 1). There was no significant difference between the tested extracts in inhibitory activity against MDRAB AB5057 and MRSA USA300 towards biofilm formation at different tested concentrations except for Cq2 $(0.625 \mathrm{mg} / \mathrm{mL})$ and Cq3 $(0.625 \mathrm{mg} / \mathrm{mL})$ against MDRAB AB5057 (two-way ANOVA and Tukey's test, $p<0.05$, Figure 1).
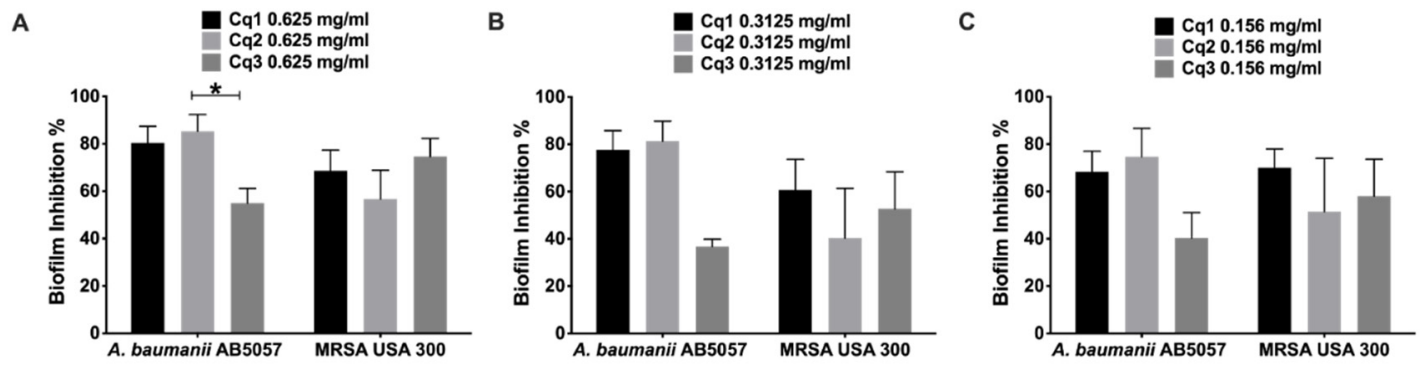

Figure 1. Biofilm inhibition activity. Effect of different concentrations (A: $0.625 \mathrm{mg} / \mathrm{mL}, \mathbf{B}: 0.3125 \mathrm{mg} / \mathrm{mL}$, and C: $0.156 \mathrm{mg} / \mathrm{mL}$ ) of Caralluma quadrangula extracts (Cq1, Cq2, and Cq3) against MDRAB AB5057 and MRSA USA300 biofilm formation. Results are expressed as mean biofilm inhibition $\% \pm$ standard error. ${ }^{*}$ Indicates that the difference is significant at $p<0.05$ (two-way ANOVA, Tukey's post-hoc test).

Interestingly, the three tested extracts showed a significant biofilm detachment activity against MRSA USA300 stronger than against A. baumannii AB5057 at all the tested concentrations $(0.625,0.313$, and $0.156 \mathrm{mg} / \mathrm{mL}$ ) (two-way ANOVA and Tukey's test, $p<0.05$ ) 
(Figure 2). Regarding the biofilm inhibition activity, there was no significant difference between the tested extract concentrations $(0.625,0.313$, and $0.156 \mathrm{mg} / \mathrm{mL})$ against the two tested pathogens (MRSA USA300 and MDRAB AB5057) (two-way ANOVA, Tukey's posthoc test, $p<0.05)$. The same was observed regarding the biofilm detachment activity except for a significant difference between the activity of extract Cq1 at concentration $0.625 \mathrm{mg} / \mathrm{mL}$ and Cq1 at the least-tested concentration $0.156 \mathrm{mg} / \mathrm{mL}$ against MRSA USA300 (two-way ANOVA, Tukey's post-hoc test, $p<0.05)$.
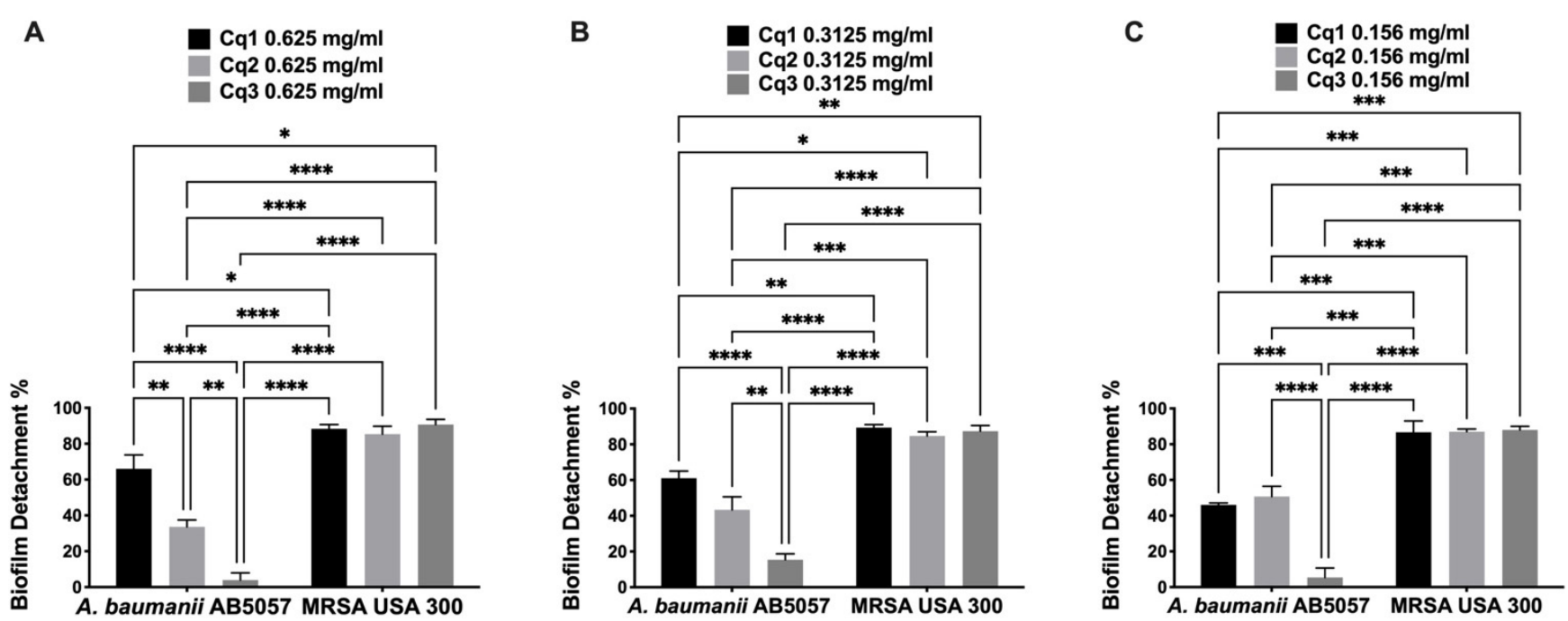

Figure 2. Biofilm detachment activity. Effect of different concentrations (A: $0.625 \mathrm{mg} / \mathrm{mL}, \mathbf{B}: 0.3125 \mathrm{mg} / \mathrm{mL}$, and C: $0.156 \mathrm{mg} / \mathrm{mL}$ ) of Caralluma quadrangula extracts (Cq1, Cq2, and Cq3) on previously established MDRAB AB5057 and MRSA USA300 biofilm. Results are expressed as mean biofilm detachment $\% \pm$ standard error. ${ }^{*},{ }^{* *},{ }^{* * *}$, and ${ }^{* * *}$ indicate that the difference is significant at $p<0.05, p<0.005, p<0.0005$, and $p<0.0001$, respectively (two-way ANOVA, Tukey's post-hoc test).

\subsection{In Vivo Evaluation of C. quadrangula Extracts against MRSA USA300 Skin Infection}

Four groups of BALB/C mice, each group composed of eight mice, were injected with MRSA USA300 intradermally. An abscess at the site of infection was developed $24 \mathrm{~h}$ after infection. C. quadrangula extracts (Cq1 and Cq3) significantly decreased the bacterial load of MRSA USA300 in comparison with vehicle control and negative control groups (one-way ANOVA and Tukey's test, $p<0.05$ ) (Figure 3). MRSA USA300 count recovered from the Cq1-treated group was 1.724 and 1.777 logs lower than that of the vehicle control and negative control groups, respectively, while the bacterial count recovered from Cq3-treated group was 2.484 and 2.537 logs lower than that of the vehicle control and negative control groups, respectively. No significant difference was found between the MRSA USA300 count recovered from the vehicle control and the negative control groups (one-way ANOVA and Tukey's test, $p<0.05$ ) (Figure 3).

\subsection{Extraction and Isolation of the Major Glycosides from N-Butanol Fraction}

Based on the results of the biofilm inhibition assay and the in vivo skin infection murine model, the $n$-butanol fraction was selected for further chromatographic separation for its bioactive components. Four major pregnane glycosides (Rus A-D) and one flavonoid (Rus E) were separated (Figure 4). The identification of the isolated compounds was achieved using ${ }^{1} \mathrm{H}$ - and ${ }^{13} \mathrm{C}-\mathrm{NMR}$ and by comparison with authentic samples previously isolated from C. russeliana [28]. 


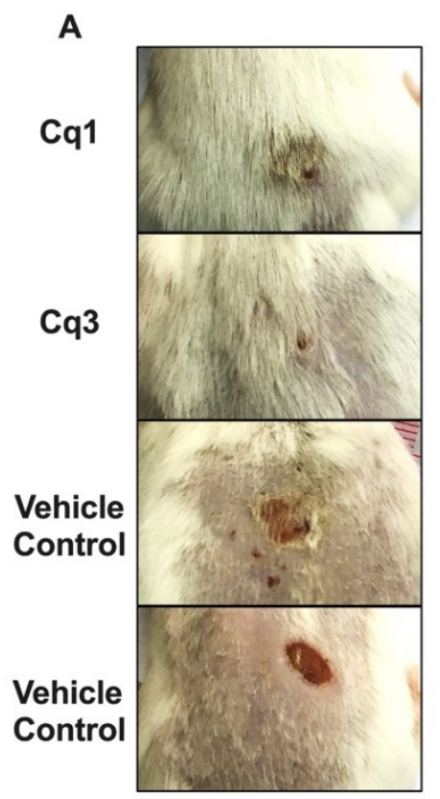

B

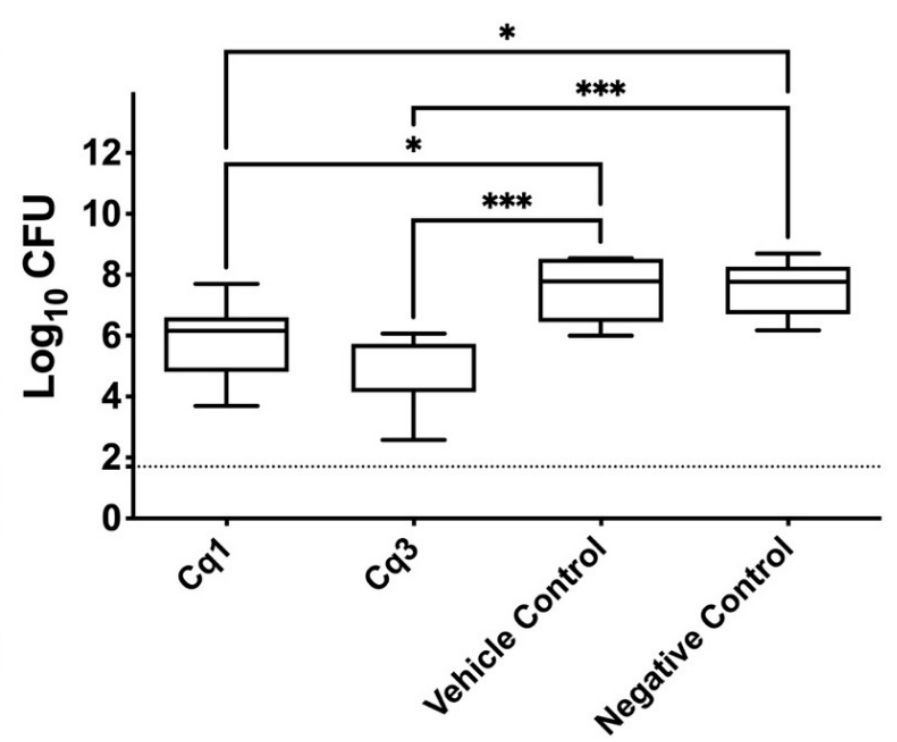

Figure 3. Efficacy of Caralluma quadrangula extracts (Cq1 and Cq3) in an in vivo murine model of MRSA skin infection. Thirty-two BALB/C mice were divided into four groups $(\mathrm{n}=8)$, three treated groups ( $\mathrm{Cq} 1, \mathrm{Cq} 3$, and vehicle), and the fourth group remained untreated as the negative control. (A) Efficacy of Caralluma quadrangula extracts (Cq1 and Cq3) on MRSA skin infection in the posterior upper backs of mice at the end of the experiment. (B) Efficacy of Caralluma quadrangula extracts on the bacterial load in murine model MRSA skin infection. Results are expressed as mean \pm standard error. The dotted line represents the limit of detection of the viable count $(\log 10$ of $50 \mathrm{CFU}=1.7)$. * and ** indicate that the difference is significant at $p<0.05$ and $p<0.0009$, respectively (one-way ANOVA, Tukey's post-hoc test).

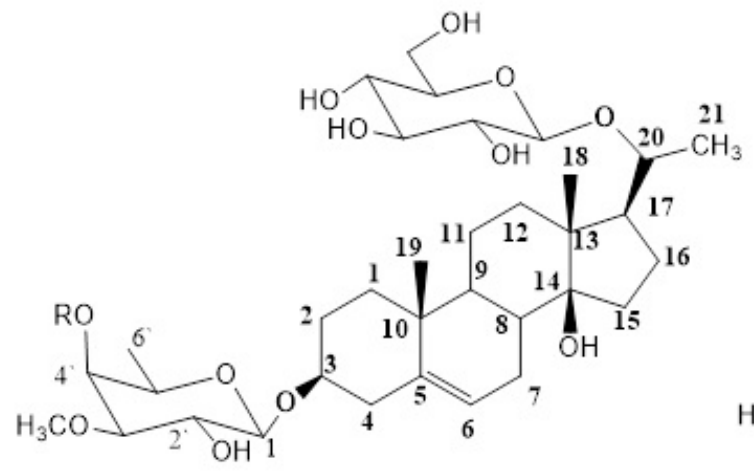

Rus A $\mathbf{R}=\mathbf{H}$

Rus B $\mathbf{R}=$ Glc

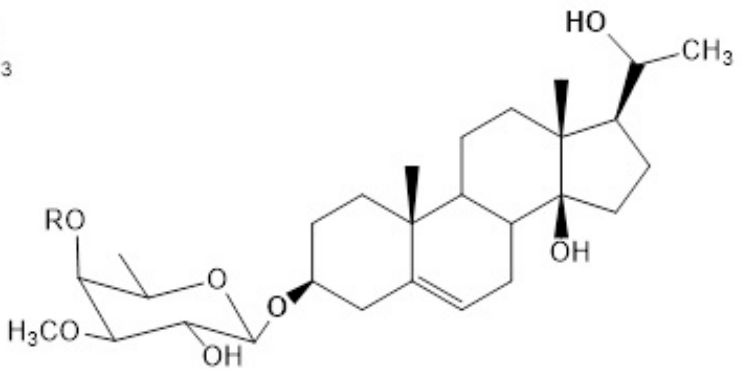

Rus C R=Glc

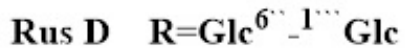<smiles>O=c1cc(-c2ccc(OC(OCC(O)C(O)C(O)CO)C(O)C(O)C(O)CO)c(O)c2)oc2cc(O)cc(O)c12</smiles>

Rus E

Figure 4. Chemical structures of russeliosides A-E. 


\subsection{MBC and Antibiofilm Assays of the Isolated Compounds}

Based on the promising activity of the tested C. quadrangula extracts against MRSA skin infection in the murine model, the isolated compounds (Rus A-E) from the active Cq3 fraction were tested for antibacterial and antivirulence (antibiofilm) activity against MRSA USA300 (Table 1). The five compounds had the same antibacterial activity against MRSA USA300 with MBC $5 \mathrm{mg} / \mathrm{mL}$. The five isolated compounds significantly inhibited the biofilm formation of MRSA USA300 at different tested concentrations (500-15.625 $\mu \mathrm{g} / \mathrm{mL})$ (two-way ANOVA and Dunnett's test, $p<0.0001$ ) (Table 1). Compound Rus C showed the highest antibiofilm activity $\left(\mathrm{IC}_{50}=0.139 \mathrm{mmole}\right)$ among all the tested concentrations, followed by compound Rus B $\left(\mathrm{IC}_{50}=0.279\right.$ mmole), and Rus E was the least with $\mathrm{IC}_{50}=0.818$ mmole (Figure $5 \mathrm{~A}$ and Table 1 ). There was no significant difference in antibiofilm activity between compounds Rus A and Rus D, IC $\mathrm{IC}_{50}=0.295$ and 0.296, respectively (two-way ANOVA and Tukey's test, $p<0.05$ ). Compound Rus $\mathbf{C}$ showed significantly higher antibiofilm activity than compounds Rus A, Rus B, and Rus E at the least-tested concentration $(15.625 \mu \mathrm{g} / \mathrm{mL} \equiv \mathrm{MBC} / 320)$ (two-way ANOVA and Tukey's test, $p<0.05)$.

Table 1. IC50 of the five isolated Caralluma quadrangula compounds (Rus A-E) against MRSA USA300 biofilm.

\begin{tabular}{|c|c|c|c|c|c|c|c|c|}
\hline & \multicolumn{4}{|c|}{ Biofilm Inhibition } & \multicolumn{4}{|c|}{ Biofilm Detachment } \\
\hline & \multirow{2}{*}{$\begin{array}{c}\operatorname{LogIC50} \pm \mathrm{SE} \\
-\end{array}$} & \multicolumn{3}{|c|}{ Mean IC50 } & \multirow{2}{*}{$\frac{\operatorname{LogIC50} \pm \mathrm{SE}}{-}$} & \multicolumn{3}{|c|}{ Mean IC50 } \\
\hline & & $(\mu \mathrm{g} / \mathrm{mL})$ & ( $\mu$ mole) & (mmol) & & $(\mu \mathrm{g} / \mathrm{mL})$ & ( $\mu$ mole) & (mmol) \\
\hline Rus A & $2.286 \pm 0.083$ & 193.2026 & $294.62 \pm$ & 0.295 & $3.62 \pm 0.318$ & 4164.101 & 6347.71 & 6.347 \\
\hline Rus B & $2.358 \pm 0.098$ & 227.9783 & 278.7 & 0.279 & $2.842 \pm 0.272$ & 694.9902 & 849.62 & 0.849 \\
\hline Rus C & $1.961 \pm 0.141$ & 91.43766 & 139.39 & 0.139 & $2.919 \pm 0.125$ & 829.7031 & 1264.79 & 1.264 \\
\hline Rus D & $2.385 \pm 0.122$ & 242.6153 & 296.6 & 0.296 & $3.166 \pm 0.496$ & 1465.124 & 1791.1 & 1.791 \\
\hline Rus E & $2.687 \pm 0.093$ & 486.1934 & 818.51 & 0.818 & $5.142 \pm 0.943$ & $138,566.6$ & $233,277.1$ & 233.277 \\
\hline
\end{tabular}

The five tested compounds significantly eradicated the previously formed MRSA USA300 biofilm at different tested concentrations (15.625-500 $\mu \mathrm{g} / \mathrm{mL}$, Figure 5B) (two-way ANOVA and Dunnett's test, $p<0.0001)$. Interestingly, Rus A showed the least biofilm detachment activity at all the tested concentrations. Rus B and Rus C showed the highest biofilm detachment activity with no significant difference between them, with $\mathrm{IC}_{50}=0.849$ and 1.264 mmole, respectively (two-way ANOVA and Tukey's test, $p<0.05$ ).

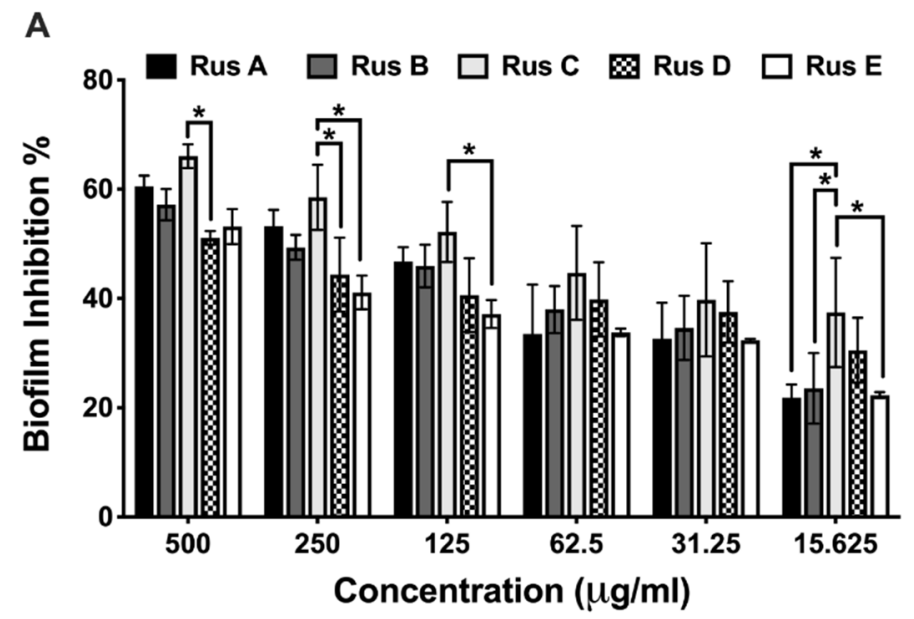

Figure 5. Cont. 


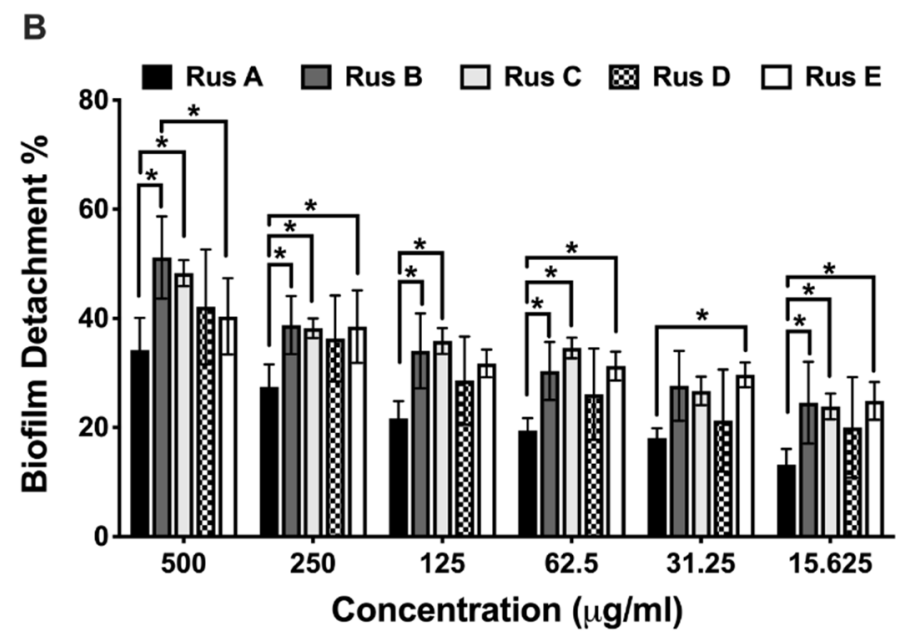

Figure 5. Antibiofilm inhibition activity. Effect of different concentrations $(500-15.625 \mu \mathrm{g} / \mathrm{mL})$ of the isolated Caralluma quadrangular compounds (Rus A-E) on MRSA USA300 biofilm. Results are expressed as mean biofilm inhibition $\% \pm$ standard error (A) and mean biofilm detachment $\% \pm$ standard error (B). ${ }^{*}$ Indicates that the difference is significant at $p<0.05$ (two-way ANOVA, Tukey's post-hoc test).

\section{Discussion}

The World Health Organization (WHO) listed methicillin-resistant S. aureus (MRSA) and A. baumannii (MDRAB) as high-priority human pathogens. Being the primary causative agent of difficult-to-treat and persistent human infections, the ability of S. aureus and A. baumannii to make biofilm plays a crucial role in antibiotic resistance development [29]. $S$. aureus plays a notable role in skin infections to life-concerning invasive illnesses such as bloodstream infections, wound infections, and infective endocarditis [30]. The capability to form biofilm on both biotic and abiotic surfaces is a vital factor and a common cause of persistent infections related to indwelling medical devices and resistance to widespectrum antimicrobial agents. The inhibition of biofilm formation will inform the cells of bacteria against host immune clearance and antibacterial therapy and prevent the progression of infection [31]. Hence, targeting biofilm is an alternate protocol to contest bacterial infections.

Our work demonstrated the biofilm inhibitory efficacy of $C$. quadrangula extracts (Cq1, Cq2, and Cq3) against MDRAB AB5057 and MRSA USA300. Furthermore, the biofilm detachment activity of $C$. quadrangula extracts (Cq1 and Cq3) and their efficacy in a murine model of skin infection were also examined. C. quadrangula extracts were tested for their biofilm inhibition activity and biofilm detachment activity at very low concentrations below their MBC. The concentrations tested against MDRAB AB5057 were 1/20, 1/40, and $1 / 80 \mathrm{MBC}$, while the concentrations tested against MRSA USA300 were $1 / 40,1 / 80$, and $1 / 160 \mathrm{MBC}$. The results confirmed that the tested extracts exhibit significant antibiofilm activity against both multidrug-resistant strains without inhibiting cell growth, hence reducing the risk of the emergence of resistance against tested extracts and adopting an antivirulence approach in fighting resistant pathogens [32]. The inhibition of biofilm growth and development is more difficult to achieve than the detachment of preformed biofilm. These results were consistent with those found in previous studies [33,34].

$S$. aureus is a common cause of superficial skin infections [35]. The treatment of $S$. aureus infections has become complicated and more difficult due to the increasing incidence of multidrug-resistant $S$. aureus strains $[36,37]$. Therefore, the progress for discovering new compounds that are active as anti-multidrug-resistant strains, particularly against MRSA, is of great need [38]. C. quadrangula extracts had potent antibacterial activity against MRSA superficial skin infections in the mice model and enhanced the recovery of the induced skin infections. The extracts (Cq1 and Cq3) significantly decreased the 
bacterial load in the induced wound when compared to the control groups. These results indicate that $C$. quadrangula is a promising antibacterial candidate to be used in topical formulations against MRSA superficial skin infections. Our findings correlate with a recent study reporting significant antivirulence of Illicium verum Hook. Polar fraction against MRSA and MDRAB [12].

After the comparison of the biofilm inhibition activity of the isolated pregnane glycosides $\left(\mathrm{IC}_{50}\right)$, we concluded that compounds with a lower number of sugar moieties at C-3 were more active (Russ C > Rus D). In the presence of two sugar moieties at C-3 (Rus B and Rus C), the absence of a sugar moiety at C-20 (Rus C) showed higher activity (Russ C > Rus B). Further future studies of more examples of pregnane glycosides are needed to find a sort of structure-activity relationship (SAR) among previously isolated pregnane glycosides.

Pregnane glycosides have been reported with interesting biological activities: antiparasitic, antimicrobial, antifungal, antisteroidogenic, anorectic, antioxidative, antiulcer, and antiarthritic [19,25-27,39]. From our study, we investigated their antibiofilm activity, where they showed significant activity. We also documented the structure-activity relationships of pregnane glycosides as antibiofilm.

\section{Materials and Methods}

\subsection{Chemicals}

Solvents used in this study were of analytical grades and purchased from El Gomhouria for Drugs Co. (Cairo, Egypt).

\subsection{Plant Material}

C. quadrangula (Forssk.) N.E.Br. (syn. Monolluma quadrangula (Forssk.) whole plant was collected from Al-Taif Governorate, Saudi Arabia, in February 2020. A specimen was left in the herbarium of Faculty of Pharmacy, Cairo University, Cairo, Egypt (No. 05.04.2020) and was authenticated by Dr. Emad Al-Sharif, Associate Professor of Plant Ecology, Department of Biology, Faculty of Science and Arts, Khulais, King Abdulaziz University, Saudi Arabia.

\subsection{Extraction and Isolation of Major Compounds}

The air-dried powder of $C$. quadrangula $(300 \mathrm{~g})$ was extracted with $\mathrm{MeOH}(3 \times 1.5 \mathrm{~L})$ using an Ultra-Turrax homogenizer to give on evaporation of the solvent $60 \mathrm{~g}$ of methanolic extract (Cq1). The methanolic extract (Cq1, $45 \mathrm{~g})$ was partitioned consecutively with methylene chloride $(4 \times 250 \mathrm{~mL})$, and $n$-butanol $(4 \times 250 \mathrm{~mL})$ to get 6.5 of methylene chloride fraction (Cq2) and $33.2 \mathrm{~g}$ of $n$-butanol fraction (Cq3). Compounds $1-5$ were isolated following the chromatography of $\mathrm{Cq} 3(20 \mathrm{~g})$ on a silica gel column adopting the method reported by Al-Yahya et al. [28]. Their spectral data $\left({ }^{1} \mathrm{H}\right.$ - and $\left.{ }^{13} \mathrm{CNMR}\right)$ were compared with those reported in the reference paper [28]. The isolated compounds (A-E) were identified as russelioside A (Rus A), russelioside B (Rus B), russelioside C (Rus C), russelioside D (Rus D), and luteolin 4'-O- $\beta$-D-neohesperidoside (Rus E). The isolated compounds were first isolated from C. russeliana [28] and further isolated from C. tuberculata (unpublished data) and quantified by LC-MS [40].

\subsection{Biological Assays}

\subsubsection{In Vitro Studies}

Bacterial Strains and Growth Conditions

We used the highly virulent MRSA (USA300) [41] and A. baumannii AB5057 [3,9] as the test organisms in this study. For biofilm assays, tryptic soy broth (TSB) and lysogeny broth (LB) were used for MRSA USA300 and multidrug-resistant A. baumannii AB5057 (MDRAB), respectively. 


\section{Minimum Bactericidal Concentration (MBC)}

The minimum bactericidal concentration (MBC) was determined by the broth microdilution method [42]. One hundred microliters of double strength sterile Mueller-Hinton broth was pipetted into each well of a U-shaped-bottom sterile microplate, and the same volume of the tested extract or compound $(100 \mathrm{mg} / \mathrm{mL}$ or $10 \mathrm{mg} / \mathrm{mL}$, respectively) or DMSO (negative control) was added to the first well of each row. Serial dilutions (two-fold) were performed across the microplates $(50-0.391 \mathrm{mg} / \mathrm{mL}$ for the extracts and $5-0.0391 \mathrm{mg} / \mathrm{mL}$ ). Ten microliters of the bacterial inoculum $\left(10^{8} \mathrm{CFU} / \mathrm{mL}\right)$ was then added to each well. The microplates were incubated for $24 \mathrm{~h}$ at $37^{\circ} \mathrm{C}$. All wells were spotted onto Mueller-Hinton plates and incubated for $24 \mathrm{~h}$ at $37^{\circ} \mathrm{C}$. The $\mathrm{MBC}$ was defined as the minimum concentration of the tested extract without detectable colonies of the target organism.

\section{Antibiofilm Screening Assay}

A static biofilm formation was assayed in a flat-bottom sterile ELISA plate as formerly reported [12]. Briefly, the bacterial suspension of MDRAB AB5057 or MRSA USA300 $\left(10^{8} \mathrm{CFU} / \mathrm{mL}\right)$ was loaded in the plates $(120 \mu \mathrm{L} /$ well $)$. The tested extract/compound (12 $\mu \mathrm{L} /$ well) was added to the bacterial suspension, and DMSO (solvent) was added instead of the tested extract/compound as the control. Each extract/compound was tested at concentrations below its MBC. The plates were incubated under static conditions. After the incubation period $(24 \mathrm{~h})$, cell growth was measured at $600 \mathrm{~nm}$ with a spectrophotometric plate reader (Biotek, Synergy 2, VT-USA). To quantify the established biofilm, each well was washed three times with saline $(400 \mu \mathrm{L} /$ well) then air-dried and stained with crystal violet $(0.1 \% w / v, 150 \mu \mathrm{L} /$ well $)$ for $30 \mathrm{~min}$. Then, the wells were rinsed three times with distilled water and left to dry completely. The crystal violet in the biofilm was solubilized by absolute ethanol $(150 \mu \mathrm{L} /$ well $)$ for $20 \mathrm{~min}$ at $4{ }^{\circ} \mathrm{C}$. The OD of the solubilized crystal violet solutions was measured by the plate reader spectrophotometer at $550 \mathrm{~nm}$. For normalization, the reading was divided by $\mathrm{OD}_{600 \mathrm{~nm}}$ of the cell growth. The results were expressed as biofilm inhibition \% using the following equation:

$$
\text { Biofilm inhbition } \%=\frac{O D \text { control }-O D \text { Test }}{O D \text { Control }} \times 100
$$

\section{Biofilm Detachment Activity}

C. quadrangula extracts (Cq1-3) and compounds (Rus A-E) were tested against previously established biofilm by MDRAB AB5057 or MRSA USA300. The assay was performed as previously reported [12]. The bacterial suspension was added to a flat-bottom ELISA plate $(120 \mu \mathrm{L} /$ well $)$ and incubated under static conditions for $24 \mathrm{~h}$ at $37^{\circ} \mathrm{C}$. Cell growth was measured at $600 \mathrm{~nm}$, then the wells were thoroughly emptied. The tested extract/compound was added $(120 \mu \mathrm{L} /$ well) at different concentrations. DMSO (solvent) was added instead of the tested extract/compound as untreated biofilm (reference value). Staining with crystal violet and measurements were applied as described above to quantify the remaining biofilm after the detachment activity of the tested extract/compound. The results were expressed as biofilm detachment $\%$ using the following equation:

$$
\text { Biofilm detachment } \%=\frac{O D \text { control }-O D \text { Test }}{\text { OD Control }} \times 100
$$

\subsubsection{In Vivo Study}

Animals

Thirty-two BALB/C mice were supplied from a local supplier (The Modern Veterinary Office for Laboratory Animals, Cairo-Egypt). The animals (8 weeks old) were sheltered in plastic cages with a pellet diet and water (temperature: $25 \pm 2{ }^{\circ} \mathrm{C}$, humidity: $50 \pm 10 \%$, and light: $12 / 12 \mathrm{~h} \mathrm{light/dark}$ cycle. The animal care and experiments were authorized by the Research Ethics Committee of the Faculty of Pharmacy, Cairo University (Approval No. 
MIC2669) and performed following the "Guide for the Care and Use of Laboratory Animals" published by the Institute of Laboratory Animal Research (Washington, DC, USA).

In Vivo Evaluation of C. quadrangula Extracts against MRSA Skin Infection in Mice

The murine model of MRSA skin infection was constructed as previously reported [12]. In brief, the upper backs of the mice were shaved and intradermally injected with $40 \mu \mathrm{L}$ of mid logarithmically grown MRSA USA300 $\left(5.5 \times 10^{8} \mathrm{CFU}\right)$ suspended in sterile buffered saline. Infected animals were randomly divided into four groups $(n=8 /$ group). Fortyeight hours after infection, mice developed an abscess at the site of infection, which later developed into an open wound. Two groups were topically treated with C. quadrangula extracts (Cq1 and Cq3) at a concentration of $100 \mathrm{mg} / \mathrm{mL}$ (4 MBC). The third group was topically treated with the vehicle ( $25 \% v / v$ DMSO in water) and used as vehicle control. The fourth group was untreated and used as a negative control. The groups were topically treated by using $100 \mu \mathrm{L}$ of the corresponding treatment once daily for three days at the site of infection. After $24 \mathrm{~h}$ from the last treatment, mice were euthanized, and the lesion was excised then homogenized in $0.5 \mathrm{~mL}$ saline (homogenizer, DAIHAN-scientific-pacificlab). Samples were diluted 10-fold and spotted on mannitol salt agar (MSA) for aerobic viable count. After incubation for $24 \mathrm{~h}$ at $37^{\circ} \mathrm{C}$, the colonies were counted, and the results of the treated groups were compared to those of the vehicle control and negative control groups.

\section{Conclusions}

C. quadrangula extract had a promising inhibition and detachment activity against biofilm formed by the highly virulent and multidrug-resistant A. baumannii AB5057 and MRSA USA300 with promising in vivo antibacterial activity against MRSA in a superficial skin infection in mice model. C. quadrangula is an effective antibiofilm agent and is a potential candidate against persistent infections of multidrug-resistant strains. These findings suggest that $C$. quadrangular may have a good potential use as an alternative defense against the rest of ESKAPE pathogens with further investigations needed to support this assumption.

Author Contributions: All authors set the main idea of the manuscript; E.A.-S. collected the plant material; E.A.-S. and R.A.E.-S. isolated and structurally identified the bioactive compounds. M.H. and R.A.H. contributed equally to all the microbiological work (both in vitro and in vivo experiments) in this study. M.H. and R.A.H. performed the experiments, established the microbiological study conception, study design, acquisition and analysis of data, and interpretation. All authors contributed equally in drafting the manuscript, revising, and critically reviewing the article. All the authors approved the submitted version. All authors have read and agreed to the published version of the manuscript.

Funding: This research received no external funding.

Institutional Review Board Statement: The animal care and experiments were authorized by the Research Ethics Committee of the Faculty of Pharmacy, Cairo University (Approval no. MIC2669) and performed following the "Guide for the Care and Use of Laboratory Animals" published by the Institute of Laboratory Animal Research (Washington, DC, USA).

Informed Consent Statement: Not applicable.

Conflicts of Interest: The authors declare no conflict of interest.

\section{References}

1. Qi, L.; Li, H.; Zhang, C.; Liang, B.; Li, J.; Wang, L.; Du, X.; Liu, X.; Qiu, S.; Song, H. Relationship between Antibiotic Resistance, Biofilm Formation, and Biofilm-Specific Resistance in Acinetobacter baumannii. Front. Microbiol. 2016, 7, 483. [CrossRef] [PubMed]

2. Genovese, C.; D’Angeli, F.; Bellia, F.; Distefano, A.; Spampinato, M.; Attanasio, F.; Nicolosi, D.; Di Salvatore, V.; Tempera, G.; Lo Furno, D.; et al. In Vitro Antibacterial, Anti-Adhesive and Anti-Biofilm Activities of Krameria lappacea (Dombey) Burdet \& B.B. Simpson Root Extract against Methicillin-Resistant Staphylococcus aureus Strains. Antibiotics 2021, 10, 428. [CrossRef] 
3. Liu, H.; Wu, Y.-Q.; Chen, L.-P.; Gao, X.; Huang, H.-N.; Qiu, F.-L.; Wu, D.-C. Biofilm-Related Genes: Analyses in MultiAntibiotic Resistant Acinetobacter baumannii isolates from Mainland China. Med. Sci. Monit. Int. Med. J. Exp. Clin. Res. 2016, 22, 1801-1807. [CrossRef] [PubMed]

4. Tan, X.; Xie, H.; Zhang, B.; Zhou, J.; Dou, Z.; Wang, X.; Wang, N. A Novel Ivermectin-Derived Compound D4 and Its Antimicrobial/Biofilm Properties against MRSA. Antibiotics 2021, 10, 208. [CrossRef]

5. Bagińska, N.; Cieślik, M.; Górski, A.; Jończyk-Matysiak, E. The Role of Antibiotic Resistant A. baumannii in the Pathogenesis of Urinary Tract Infection and the Potential of Its Treatment with the Use of Bacteriophage Therapy. Antibiotics 2021, 10, 281. [CrossRef]

6. Delancey, E.; Allison, D.; Kc, H.R.; Gilmore, D.F.; Fite, T.; Basnakian, A.G.; Alam, M.A. Synthesis of 4,4'-(4-Formyl-1H-pyrazole1,3-diyl)dibenzoic Acid Derivatives as Narrow Spectrum Antibiotics for the Potential Treatment of Acinetobacter Baumannii Infections. Antibiotics 2020, 9, 650. [CrossRef] [PubMed]

7. Han, H.-W.; Kwak, J.-H.; Jang, T.-S.; Knowles, J.C.; Kim, H.-W.; Lee, H.-H.; Lee, J.-H. Grapefruit Seed Extract as a Natural Derived Antibacterial Substance against Multidrug-Resistant Bacteria. Antibiotics 2021, 10, 85. [CrossRef] [PubMed]

8. Xiong, Y.Q.; Estellés, A.; Li, L.; Abdelhady, W.; Gonzales, R.; Bayer, A.S.; Tenorio, E.; Leighton, A.; Ryser, S.; Kauvar, L.M. A Human Biofilm-Disrupting Monoclonal Antibody Potentiates Antibiotic Efficacy in Rodent Models of both Staphylococcus aureus and Acinetobacter baumannii Infections. Antimicrob. Agents Chemother. 2017, 61, e00904-e00917. [CrossRef]

9. Jacobs, A.C.; Thompson, M.G.; Black, C.C.; Kessler, J.L.; Clark, L.P.; McQueary, C.N.; Gancz, H.Y.; Corey, B.W.; Moon, J.K.; Si, Y.; et al. AB5075, a Highly Virulent Isolate of Acinetobacter baumannii, as a Model Strain for the Evaluation of Pathogenesis and Antimicrobial Treatments. mBio 2014, 5, e01076. [CrossRef]

10. Lesho, E.; Yoon, E.J.; McGann, P.; Snesrud, E.; Kwak, Y.; Milillo, M.; Onmus-Leone, F.; Preston, L.; St Clair, K.; Nikolich, M.; et al. Emergence of colistin-resistance in extremely drug-resistant Acinetobacter baumannii containing a novel pmrCAB operon during colistin therapy of wound infections. J. Infect. Dis. 2013, 208, 1142-1151. [CrossRef] [PubMed]

11. Boucher, H.W.; Talbot, G.H.; Bradley, J.S.; Edwards, J.E.; Gilbert, D.; Rice, L.B.; Scheld, M.; Spellberg, B.; Bartlett, J. Bad bugs, no drugs: No ESKAPE! An update from the Infectious Diseases Society of America. Clin. Infect. Dis. 2009, 48, 1-12. [CrossRef]

12. Salem, M.A.; El-Shiekh, R.A.; Hashem, R.A.; Hassan, M. In vivo Antibacterial Activity of Star Anise (Illicium verum Hook.) Extract Using Murine MRSA Skin Infection Model in Relation to Its Metabolite Profile. Infect. Drug Resist. 2021, 14, 33-48. [CrossRef]

13. Ezzat, M.I.; Hassan, M.; Abdelhalim, M.A.; El-Desoky, A.M.; Mohamed, S.O.; Ezzat, S.M. Immunomodulatory effect of Noni fruit and its isolates: Insights into cell-mediated immune response and inhibition of LPS-induced THP-1 macrophage inflammation. Food Funct. 2021, 12, 3170-3179. [CrossRef]

14. Elzeini, H.M.; Ali, A.R.A.A.; Nasr, N.F.; Hassan, M.; Hassan, A.A.m.; Elenany, Y.E. Probiotic capability of novel lactic acid bacteria isolated from worker honey bees gut microbiota. FEMS Microbiol. Lett. 2021, 368. [CrossRef]

15. Bin-Jumah, M.N. Antidiabetic Effect of Monolluma quadrangula Is Mediated via Modulation of Glucose Metabolizing Enzymes, Antioxidant Defenses, and Adiponectin in Type 2 Diabetic Rats. Oxid. Med. Cell. Longev. 2019, 2019, 6290143. [CrossRef]

16. Adnan, M.; Jan, S.; Mussarat, S.; Tariq, A.; Begum, S.; Afroz, A.; Shinwari, Z.K. A review on ethnobotany, phytochemistry and pharmacology of plant genus Caralluma r. Br. J. Pharm. Pharmacol. 2014, 66, 1351-1368. [CrossRef]

17. Farouk, A.-E.; Ahamed, N.T.; AlZahrani, O.; Alamer, K.H.; Al-Sodany, Y.; Bahobail, A.A. Antimicrobial Activity of Caralluma quadrangula (Forssk) N.E. Br Latex from Al-Shafa Taif, Kingdom of Saudi Arabia. Int. J. Curr. Microbiol. Appl. Sci. 2016, 5, 284-298. [CrossRef]

18. Babu, K.S.; Malladi, S.; Nadh, R.V.; Rambabu, S.S. Evaluation of in Vitro Antibacterial Activity of Caralluma umbellata Haw Used in Traditional Medicine by Indian Tribes. Annu. Res. Rev. Biol. 2013, 4, 840-855. [CrossRef]

19. Reddy, K.D.; Reddy, K.H.; Rao, G.V.; Brenda, M.; Patrick, G.; Koorbanally, N.A. In vitro Antimicrobial, Antioxidant and Cytotoxic Activities of New Pregnane Glycosides and Pregnanes Isolated from the Carallum adescendens var. gracilis and Caralluma pauciflora. J. Pure Appl. Microbiol. 2013, 7, 2707-2712.

20. Malladi, S.; Ratnakaram, V.N.; Suresh Babu, K.; Pullaiah, T. Evaluation of in vitro antibacterial activity of Caralluma lasiantha for scientific validation of Indian traditional medicine. Cogent Chem. 2017, 3, 1374821. [CrossRef]

21. Amrati, F.E.; Bourhia, M.; Saghrouchni, H.; Slighoua, M.; Grafov, A.; Ullah, R.; Ezzeldin, E.; Mostafa, G.A.; Bari, A.; Ibenmoussa, S.; et al. Caralluma europaea (Guss.) N.E.Br.: Anti-Inflammatory, Antifungal, and Antibacterial Activities against Nosocomial Antibiotic-Resistant Microbes of Chemically Characterized Fractions. Molecules 2021, 26, 636. [CrossRef]

22. Gushash, A. Plants in the Mountains of Sarat and Hejaz; Sarawat Designer and Printers: Madinah, Saudi Arabia, 2006.

23. Abdel-Sattar, E.; El-Maraghy, S.A.; El-Dine, R.S.; Rizk, S.M. Antihyperglycemic activity of Caralluma quadrangula in streptozotocininduced diabetic rats. Bull. Fac. Pharm. Cairo Univ. 2017, 55, 269-272. [CrossRef]

24. Abdel-Sattar, E.; El-Maraghy, S.A.; El-Dine, R.S.; Rizk, S.M. Russelioside B, a pregnane glycoside ameliorates hyperglycemia in streptozotocin induced diabetic rats by regulating key enzymes of glucose metabolism. Chem. Biol. Interact. 2016, 252, 47-53. [CrossRef]

25. Abdel-Sattar, E.; Mehanna, E.T.; El-Ghaiesh, S.H.; Mohammad, H.M.F.; Elgendy, H.A.; Zaitone, S.A. Pharmacological Action of a Pregnane Glycoside, Russelioside B, in Dietary Obese Rats: Impact on Weight Gain and Energy Expenditure. Front. Pharmacol. 2018, 9, 990. [CrossRef]

26. El-Shiekh, R.A.; El-Mekkawy, S.; Mouneir, S.M.; Hassan, A.; Abdel-Sattar, E. Therapeutic potential of russelioside B as anti-arthritic agent in Freund's adjuvant-induced arthritis in rats. J. Ethnopharmacol. 2021, 270, 113779. [CrossRef] [PubMed] 
27. El-Shiekh, R.A.; Salama, A.; Al-Mokaddem, A.K.; Bader, A.; Abdel-Sattar, E.A. Russelioside B, a pregnane glycoside for treatment of gastric ulcer via modulation of heat shock protein-70 and vascular endothelial growth factor. Steroids 2021, 165, 108759. [CrossRef]

28. Abdul-Aziz Al-Yahya, M.; Abdel-Sattar, E.; Guittet, E. Pregnane glycosides from Caralluma russeliana. J. Nat. Prod. 2000, 63, 1451-1453. [CrossRef]

29. Govindaraj Vaithinathan, A.; Vanitha, A. WHO global priority pathogens list on antibiotic resistance: An urgent need for action to integrate One Health data. Perspect. Public Health 2018, 138, 87-88. [CrossRef]

30. Tong, S.Y.; Davis, J.S.; Eichenberger, E.; Holland, T.L.; Fowler, V.G., Jr. Staphylococcus aureus infections: Epidemiology, pathophysiology, clinical manifestations, and management. Clin. Microbiol. Rev. 2015, 28, 603-661. [CrossRef]

31. Belanger, C.R.; Mansour, S.C.; Pletzer, D.; Hancock, R.E.W. Alternative strategies for the study and treatment of clinical bacterial biofilms. Emerg. Top. Life Sci. 2017, 1, 41-53. [CrossRef]

32. Imperi, F.; Fiscarelli, E.V.; Visaggio, D.; Leoni, L.; Visca, P. Activity and Impact on Resistance Development of Two Antivirulence Fluoropyrimidine Drugs in Pseudomonas aeruginosa. Front. Cell. Infect. Microbiol. 2019, 9, 49. [CrossRef]

33. Krysinski, E.P.; Brown, L.J.; Marchisello, T.J. Effect of cleaners and sanitizers on Listeria monocytogenes attached to product contact surfaces. J. Food Prot. 1992, 55, 246-251. [CrossRef]

34. Sandasi, M.; Leonard, C.M.; Viljoen, A.M. The in vitro antibiofilm activity of selected culinary herbs and medicinal plants against Listeria monocytogenes. Lett. Appl. Microbiol. 2010, 50, 30-35. [CrossRef] [PubMed]

35. Ferreira, C.; Costa, S.S.; Serrano, M.; Oliveira, K.; Trigueiro, G.; Pomba, C.; Couto, I. Clonal Lineages, Antimicrobial Resistance, and PVL Carriage of Staphylococcus aureus Associated to Skin and Soft-Tissue Infections from Ambulatory Patients in Portugal. Antibiotics 2021, 10, 345. [CrossRef]

36. Lowy, F.D. Staphylococcus aureus infections. N. Engl. J. Med. 1998, 339, 520-532. [CrossRef]

37. Chiller, K.; Selkin, B.A.; Murakawa, G.J. Skin microflora and bacterial infections of the skin. J. Investig. Dermatol. Symp. Proc. 2001, 6, 170-174. [CrossRef]

38. Buommino, E.; Vollaro, A.; Nocera, F.P.; Lembo, F.; DellaGreca, M.; De Martino, L.; Catania, M.R. Synergistic Effect of Abietic Acid with Oxacillin against Methicillin-Resistant Staphylococcus pseudintermedius. Antibiotics 2021, 10, 80. [CrossRef]

39. Komarnytsky, S.; Esposito, D.; Poulev, A.; Raskin, I. Pregnane glycosides interfere with steroidogenic enzymes to down-regulate corticosteroid production in human adrenocortical H295R cells. J. Cell. Physiol. 2013, 228, 1120-1126. [CrossRef]

40. Abdel-Sattar, E.A.; Abdallah, H.M.; Khedr, A.; Abdel-Naim, A.B.; Shehata, I.A. Antihyperglycemic activity of Caralluma tuberculata in streptozotocin-induced diabetic rats. Food Chem. Toxicol. 2013, 59, 111-117. [CrossRef]

41. Diep, B.A.; Gill, S.R.; Chang, R.F.; Phan, T.H.; Chen, J.H.; Davidson, M.G.; Lin, F.; Lin, J.; Carleton, H.A.; Mongodin, E.F.; et al. Complete genome sequence of USA300, an epidemic clone of community-acquired meticillin-resistant Staphylococcus aureus. Lancet 2006, 367, 731-739. [CrossRef]

42. Humphries, R.M.; Ambler, J.; Mitchell, S.L.; Castanheira, M.; Dingle, T.; Hindler, J.A.; Koeth, L.; Sei, K.; CLSI Methods Development and Standardization Working Group of the Subcommittee on Antimicrobial Susceptibility Testing. CLSI Methods Development and Standardization Working Group Best Practices for Evaluation of Antimicrobial Susceptibility Tests. J. Clin. Microbiol. 2018, 56, e01934-17. [CrossRef] 